\title{
RUNAWAY CHILDREN AND STARVATION
}

\section{Marino Varricchio}

Universita degli Studi di Trento, Trento, TN, Italy

\author{
Walter E. Block \\ Harold E. Wirth Eminent Scholar Endowed Chair and Professor of \\ Economics, Loyola University New Orleans, New Orleans, USA
}

OMESTE

JEL category: K19

\begin{abstract}
In this paper, we argue that Rothbard's version of the non-aggression principle, in conjunction with his account of self-ownership, is flawed. He interprets several acts that should be considered legal as criminal. First, he allows a three-year child to run away from his non-abusive parents and criminalizes the latter if they forcibly prevent this. Second, this author prohibits parents from forcing their two-yearold child to eat and drink, or have his diaper changed, when the baby refuses. We do not at all oppose the non-aggression principle. On the contrary, we reject Rothbard's interpretation of it when he applies it to children. Our main criticism is that this author is contradictory with regards to the legal status of the relationship children/parents. First, he argues that parents, despite several limitations, own their children Second, he states that children are self-owners. If this is the case, every aggression against them should be considered a criminal act. However, since parents stand in a special legal relationship with their children, certain forms of aggression committed by them are legally permissible and, in certain cases, compulsory.
\end{abstract}

Keywords: Libertarianism; the non-aggression principle; children's rights; parental rights; homesteading

\section{INTRODUCTION}

We acknowledge Rothbard as one of the preeminent libertarian theoreticians. It is not for nothing that he is commonly referred to as "Mr. Libertarian." At the very core of this philosophy is the NAP, which he has done more than any other scholar to develop. We think he applies this insight brilliantly to many different and difficult issues.

Address of the corresponding author: Marino Varricchio

㭋="marinovarricchio@gmail.com
However, when it comes to children and their rights, and the rights of their parents or guardians, we think him in error. In section II of this paper, we begin with some comments on the NAP and selfownership. Section III is devoted to our claim that regarding the legal status of children Rothbard contradicts himself. The focus of section IV is on runaway children. May guardians prevent underage tots from starving themselves? We answer strongly in the positive on this matter in section V. Section VI is our conclusion. 


\section{SOME COMMENTS ON THE NAP} AND SELF-OWNERSHIP

Murray Rothbard is widely and appropriately credited with the formulation of the definitive version of the principle of non-aggression: "The libertarian creed rests upon one central axiom: that no man or group of men may aggress against the person or property of anyone else." (Rothbard, 1973 , p. 27) Aggression is understood as "the initiation of the use or threat of physical violence against the person or property of anyone else." (Rothbard, 1973, p. 27) Therefore, according to Rothbard, a criminal "is anyone who initiates violence against another man and his property" (Rothbard, 1973, p. 51).

Rothbard's version of the principle of nonaggression appears to be without exception or absolute ${ }^{1}$. In other words, it seems to us that he thinks aggressing against an innocent individual is a legal wrong regardless of the person, the time and/or the circumstances ${ }^{2}$. This passage, referring to self-ownership, appears to confirm our hypothesis: "The right to self-ownership asserts the absolute right of each man, by virtue of his (or her) being a human being, to 'own' his or her own body; that is, to control that body free of coercive interference." (Rothbard, 1973, p. 34) ${ }^{3}$ If everyone has an absolute right to the control and ownership of his own body, then undesired aggression is legally wrong everywhere, every time and against every person.

\section{THE LEGAL STATUS OF CHILDREN: ROTHBARD'S CONTRADICTION}

Are children self-owners? What is the legal nature of the relationship with their caretakers? According to Rothbard, parents are the legitimate owners of their children, having created them (Rothbard, 1998, p. 100): "Suppose now that the baby has been born. So, what? First, we may say that the parents - or rather the mother, who is

1 For versions of the principle of non-aggression supportive of Rothbard's, see: Hoppe $(1989,1993)$ and Kinsella (1992).

2 In other words, a right is absolute if and only if is "conclusively valid without any exceptions". See Gewirth (1981).

${ }^{3}$ See also (Rothbard, 1998, p. 60) the only certain and visible parent - as the creators of its baby become its owners. A newborn baby cannot be an existent self-owner in any sense." However, he thinks that their ownership is justified albeit limited in time and in kind. There are actions that parents cannot legitimately do with their children, e.g., torturing or murdering them (Rothbard, 1998, p. 100). As Rothbard put it, "the parental ownership is not absolute but of a "trustee" or guardianship kind." (Rothbard, 1998, p. 100) However, later, strangely enough, Rothbard goes on to argue that children are selfowners: "every baby ... possesses the right of selfownership by virtue of being a separate entity and a potential adult." (Rothbard, 1998, p. 100) Therefore, in virtue of self-ownership, children are protected from every form of aggression.

Rothbard, first argues that parents own, despite several restrictions, their children. Later, however, he states that children are self-owners. By Rothbard's definition, then, if children are selfowners, then they have the absolute legal right ${ }^{4}$ not to be aggressed against. Since every right implies a correlative duty, the others, including their parents, have the duty not to aggress against them ${ }^{5}$. In a nutshell, Rothbard arrives at two different conclusions on two different occasions:

1. Parents own, although with several restrictions, their children

2. Children own themselves

1 and 2 are contradictory. In fact, it is self-evident that children's self-ownership, at least following Rothbard's definition of absolute self-ownership, is incompatible with parental guardianship.

One way to reconcile 1 with 2 would be to simply follow our intuitions. As far as the legal relationship between children and parents is concerned, common sense tells us, in Block's (et al) words, that "some degree of aggression is unavoidable. And not only unavoidable but also justified. Young children are unable to care for themselves. Caretakers must necessarily exercise a certain

\footnotetext{
${ }^{4}$ Rights are understood as claims against others. See Feinberg (1970) and Hohfeld (1913, 1917).

${ }^{5}$ For an exposition and/or a defence of the thesis of the correlativity of rights and duties, see Feinberg (1966); Hohfeld (1913, 1917), Lyons (1970), Ross (1930, pp. 48-56), and Wenar (2005).
} 
amount of 'aggression' for the child's benefit: carrying, feeding, and nurturing the child without his consent." (Block, Smith \& Reel, 2014) 6 If some degree of coercion is acceptable and intuitively plausible, then children's self-ownership is not absolute. In other words, we can reconcile 1 with 2 by saying that children are not self-owners tout court. Parents, as caretakers, stand in a special relationship with them ${ }^{7}$. They have the right to violate their children's self-ownership to care for them. Our argument has the form of a modus tollens:

1. If children are absolute self-owners, then their caretakers cannot aggress them.

2. However, a certain degree of aggression from their caretakers is legitimate.

3. Therefore, children are not absolute selfowners.

The point is, a guardian is supposed to, wait for it, guard. But good guardianship means, preeminently that the custodian acts within the child's best interest, whether or not the latter agrees. The ward would not be a ward if he could properly take care of himself. But the four-year-old child is not yet mature enough for that. If he wants to "play in traffic" the guardian well within his rights to prohibit such a dangerous activity. If he did not, then he would be renouncing his responsibility. He would be guilty of child abuse by omission.

\section{RUNAWAY CHILDREN}

Suppose that a three-year child wants to eat an entire bag of marshmallows and his parents, worried about his health, prevent him from doing so. The child, then, decides to run away from home. According to Rothbard, this spoiled child is a self-owner. Accordingly, if his parents try to prevent him from running away, or, failing that, attempted to take him back against his will, they would be aggressing against him, thus violating his basic rights. As Rothbard put it: "Regardless of his age, we must grant to every child the absolute right to run away ... Parents may try to persuade the runaway child to return, but it is totally impermissible enslavement and an aggression upon his right of self-ownership for them to use force to compel him to return." (Rothbard, 1998, p. 103) Therefore, according to Rothbard, these parents would be criminal and legally punishable for forcibly preventing him from running away or taking back home through physical force their fouryear-old child, who ran away for a bag of marshmallows. Bringing Rothbard's argument to its logical conclusions, these parents could be charged with-kidnapping.

Our theory offers a more plausible explanation of this scenario. This spoiled child is not an absolute self-owner. His parents, as caretakers, stand in a special relationship with him. Therefore, they could aggress him, albeit only for his benefit. Accordingly, taking him back is a perfectly legitimate action.

Suppose, now, that this child runs away not for being balked about a bag of marshmallows, but because his parents tortured him. According to Rothbard's theory, every form of torture is an aggression. Since every form of aggression is illegal, his parents are criminal. Their child, then, has the right to run away from them and his parents have the duty not to forcibly refrain him from doing so, in the same way, that a victim has the right to run away from his perpetrator.

Our theory arrives at the same (plausible) conclusion but for different reasons. In fact, the child has the right to run away and not to be stopped by his parents not because his parents aggressed against him, but because their aggression was illegitimate. His parents, having tortured him, did something that was not for his benefit, but, rather, the very opposite. Therefore, they gave up the role of caretakers. So, they no longer stood in a special relationship with their child. Therefore, they have now the duty not to aggress their child. They, in turn, are criminals of perhaps the worst sort, and ought to be dealt with to the full extent of the very draconian libertarian law. ${ }^{8}$

There is a third option, an intermediary one: childhood emancipation. (Wikipedia, 2018) Here, there is no child abuse, and it usually applies to children a bit older than we have been considering,

\footnotetext{
${ }^{6}$ For further discussion, see Lipson \& Vallentyne (1991). relationship with him

7 It is obvious that if a child has no parents, his caretakers, whoever they are, stand in a special

${ }^{8}$ See on this Kinsella $(1996,1997)$, and Whitehead \& Block (2003).
} 
although this is by no means required. Often, the cases involved are child actors or musicians, those who financially earn enough to support themselves, this is not necessary either. What is mandatory is that one, there be some other guardians willing to mentor this child, two that a competent court supervises the proceedings and approve of the transfer, and that the child is old enough (ten years old?) to understand precisely what is going on. If the present authors were the judges involved, we would stipulate that a trial period of perhaps a month or so be conducted, so that the child would be able to change his mind if unhappy.

Bill and Melinda Gates, presumably, have more to offer most children than their parents. They can make available to them the finest quality of all products and services. May they seize, through a court order, the children of ordinary middle-class parents who love and care for their children on this ground? Of course not. The latter do not own their children, but they are the legitimate owners of the guardianship rights over them. As long as they continue to "homestead" these rights through good care, these cannot be taken away from them. However, if a twelve-year-old wants to leave home and has another guardian willing to take on this responsibility, and if a court approves, then this would be legitimate. So, we take an intermediate position between that of Rothbard, for whom parental guardianship rights do not stretch so far as to use force to protect them, and a utilitarian position in which the Gates' of the world can commandeer children.

\section{STARVATION}

Now, suppose that a three-year-old child has not eaten for an entire day. Their parents, seriously worried about his health, force him to eat some food to save his life. According to Rothbard's theory, their action is a form of unjustified aggression. They would be considered criminal for feeding their starving child.

The child, as a self-owner, has the absolute right to control and use his body as he thinks fit. Therefore, the has the right to let himself die free of coercive interference. In Rothbard's view, letting the child die is legitimate for two reasons: first, parents have not the right to aggress their children; second, even in case the child wanted to eat, parents would not have the legal obligation to fulfill his request ${ }^{9}$. Indeed, having the legal obligation to feed one's child amounts to an illegitimate compulsion: "Applying our theory to parents and children, this means that a parent does not have the right to aggress against his children, but also that the parent should not have a legal obligation to feed, clothe or educate his children, since such obligations would entail positive acts coerced upon the parent and depriving the parent of his rights. ... But the parent should have the legal right not to feed the child, i.e., to allow it to die. The law, therefore, may not properly compel the parent to feed a child or keep it alive." (Rothbard, 1998, p.100)

Our theory, once again, arrives at more plausible and desirable conclusions. The starving child's parents, as his caretakers, can legitimately force their child to eat.

But, may that starve their progeny, claiming they have no obligation to feed them? We acquiesce to the notion that there are no positive obligations, and that therefore parents should not be legally required to do so. However, we also take the position that they are criminals if they do not take their spurned child to an orphanage, a hospital, a police station, a religious organization, where they will be fed and otherwise cared for.

But would this not be a positive obligation, contrary to basic libertarian theory? In a word, no. This requirement stems not from any positive obligation. Rather, it may logically be deduced from homesteading ${ }^{10}$ theory.

Let us explain. No one may properly control land he has not homesteaded. However, suppose someone mixes his labor with land in the format of a bagel or a donut. Suppose that is, that he

2006, 2009A, 2009B, 2009C), Locke (1948), Paul (1987), Pufendorf (1673), Rothbard (1969, 1973), Rozeff (2005), Watner (1982).
${ }^{9}$ According to libertarians, there are no positive rights. See, for example, Gordon, 2004; Long 2010.

10 Block (1990, 2002A, 2002B), Block \& Edelstein (2012), Block \& Nelson (2015), Block \& Yeatts (19992000), Block vs Epstein (2005), Bylund (2005, 2012), Grotius (1625), Hoppe (1993, 2011), Kinsella (2003, 
homesteads nine square miles in a circular pattern but leaves vacant the one square mile in the midst of his otherwise legitimate holdings. Posit that there are no bridges nor tunnels, not helicopters nor airplanes available. Then, this homesteader controls that land in the middle of his property, in that he can preclude anyone else from accessing that left-over terrain. He would guilty of the crime of forestalling or precluding. $\mathrm{He}$ is preventing others from homesteading virgin land, a criminal act.

In like manner, if parents starve their children, without notifying anyone else of their decision, they are precluding, or preventing, others from homesteading not their progeny, but, rather, the right to homestead this "virgin material" the children. For, no one can own a child, in our view, but we can own the right to be this child's guardian.
This is attained by giving birth to the baby but can only be kept by continuous "homesteading" of this young human being, namely, caring for him. The moment so much as one meal is missed ${ }^{11}$ the parents lose their guardianship rights. If they do not notify others of their decision they are guilty of a crime akin to the one committed by the donut homesteader. ${ }^{12}$

\section{CONCLUSION}

Rothbard's theory of absolute self-ownership, applied to children, leads to highly questionable conclusions. On the contrary, our theory, by accommodating the legal intuition that the caretakers of a child are legitimated to exercise a certain amount of aggression, can satisfactorily account for cases that Rothbard's theory cannot deal with properly.

\section{WORKS CITED}

Block, Walter E. (1977 Sep). Toward a Libertarian Theory of Abortion. The Libertarian Forum. 10(9), 68. http://www.mises.org/journals/lf/1977/1977_09.pdf

Block, Walter E. (1990). Earning Happiness Through Homesteading Unowned Land: a comment on 'Buying Misery with Federal Land' by Richard Stroup. Journal of Social Political and Economic Studies, 15(2), 237-253.

Block, W. \& Yeatts, G. (1999-2000). The Economics and Ethics of Land Reform: A Critique of the Pontifical Council for Justice and Peace's 'Toward a Better Distribution of Land: The Challenge of Agrarian Reform'. Journal of Natural Resources and Environmental Law, 15(1), 37-69.

Block, W.E. (2001 Sep. 3). Stem Cell Research: The Libertarian Compromise. Retrieved from: http://archive.lewrockwell.com/block/block5.html

Block, W.E. (2002A). Homesteading City Streets; An Exercise in Managerial Theory. Planning and Markets, 5(1), 18-23. Retrieved from: http://www-pam.usc.edu/volume5/v5i1a2s1.html

Block, W.E. (2002B). On Reparations to Blacks for Slavery. Human Rights Review, 3(4), 53-73.

Block, W.E. (2003). Libertarianism vs. Objectivism; A Response to Peter Schwartz. Reason Papers, 26, 39-62; Retrieved from http://www.reasonpapers.com/pdf/26/rp_26_4.pdf

Block, W.E. (2004). Libertarianism, Positive Obligations, and Property Abandonment: Children's Rights, International Journal of Social Economics, 31(3), 275-286. Retrieved from http://www.walterblock.com/wp-content/uploads/publications/block-children.pdf

Block, W. v. Epstein R. (2005). Debate on Eminent Domain. NYU Journal of Law \& Liberty, 1(3), 11441169.

Block, W.E., \& Whitehead, R. (2005). Compromising the Uncompromisable: A Private Property Rights Approach to Resolving the Abortion Controversy. Appalachian Law Review, 4(2) 1-45. Retrieved from http://www.walterblock.com/wp-content/uploads/publications/block-whitehead_abortion2005.pdf

\footnotetext{
${ }^{11}$ We exaggerate here. There might be extenuating circumstances.
} 2008, 2010A, 2010B, 2011, 2016), Block \& Whitehead

12 For more on this see: Block (1977, 2001, 2003, 2004, 
Block, W.E. (2008). Homesteading, ad coelum, owning views and forestalling. The Social Sciences, 3(2), 96-103. http://papers.ssrn.com/sol3/papers.cfm?abstract_id=1890872

Block, W.E. (2010A). A libertarian perspective on the stem cell debate: compromising the uncompromisable. Journal of Medicine and Philosophy, 35(4), 429-448. Retrieved from https://academic.oup.com/jmp/article-abstract/35/4/429/858237

Block, W.E. (2010B). Van Dun on Freedom and Property: A Critique. Libertarian Papers, 2(4), 1-11. Retrieved from http://libertarianpapers.org/wp-content/uploads/article/2010/lp-2-4.pdf

Block, W.E. (2011). Terri Schiavo: A Libertarian Analysis. Journal of Libertarian Studies, 22, 527-536. http://mises.org/journals/jls/22_1/22_1_26.pdf

Block, W.E. \& Edelstein, M.R. (2012). Popsicle sticks and homesteading land for nature preserves. Romanian Economic and Business Review, 7(1), 7-13. Retrieved from http://www.rebe.rau.ro/REBE\%207\%201.pdf

Block, W.E., Smith, E., \& Reel, J. (2014). The Natural Rights of Children. International Journal of Health Policy and Management, 2(2), 85-89.

Block, W.E., \& Nelson, P.L. (2015). Water Capitalism: The Case for Privatizing Oceans, Rivers, Lakes, and Aquifers. New York City, N.Y.: Lexington Books; Rowman and Littlefield; Retrieved from https://rowman.com/ISBN/9781498518802/Water-Capitalism-The-Case-for-PrivatizingOceans-Rivers-Lakes-and-Aquifers.

Block, W.E. (2016). Forestalling, positive obligations and the Lockean and Blockian provisos: Rejoinder to Stephan Kinsella. Ekonomia Wroclaw Economic Review. Retrieved from http://ekon.sjol.eu/category/22-3-2016-529

Bylund, P. (2005 June). Man and Matter: A Philosophical Inquiry into the Justification of Ownership in Land from the Basis of Self-Ownership. Master thesis, Lund University. Retrieved from http://www.uppsatser.se/uppsats/a7eb17de8f/;

Bylund, P. (2012). Man and matter: How the former gains ownership of the latter. Libertarian Papers, 4(1). Retrieved from http://libertarianpapers.org/articles/2012/lp-4-1-5.pdf

Feinberg, J. (1966 April). Duties, Rights, and Claims. American Philosophical Quarterly, 3(2), 137-144.

Feinberg, J. (1970 Dec). The Nature and Value of Rights. Journal of Value Inquiry, 4(4), 243-260

Gewirth, A. (1981 Jan). Are There Any Absolute Rights?. The Philosophical Quarterly, 31(122), 1-16.

Gordon, D. (2004 Fall). Liberty and Obedience. The Mises Review, 10(3).

Grotius, H. (1625). Law of War and Peace (De Jure Belli ac Pacis), 3 volumes. translated by A.C. Campbell, London, 1814.

Hohfeld, W. (1913 Nov). Fundamental Legal Conceptions as Applied in Judicial Reasoning. The Yale Law Journal, 23(1), 16-59.

Hohfeld, W. (1917 June). Fundamental Legal Conceptions as Applied in Judicial Reasoning. The Yale Law Journal, 26(8), 710-770.

Hoppe, H-H. (1989). A Theory of Socialism and Capitalism. Economics, Politics and Ethics, Boston, MA: Kluwer.

Hoppe, H-H. (1993). The Economics and Ethics of Private Property: Studies in Political Economy and Philosophy. Boston: Kluwer.

Hoppe, H-H. (2011). Of Private, Common, and Public Property and the Rationale for Total Privatization, Libertarian Papers, 3(1), 1-13. Retrieved from http://libertarianpapers.org/2011/1-hoppeprivate-common-and-public-property/

Kinsella, S. (1992). Estoppel: A New Justification for Individual Rights. Reason Papers, 17, 61-74.

Kinsella, S. (1996 Spring). Punishment and Proportionality: The Estoppel Approach. The Journal of 
Libertarian Studies, 12(1), 51-74.

Kinsella, S. (1997). A Libertarian Theory of Punishment and Rights. Loyola of Los Angeles Law Review, 607-645. Retrieved from http://digitalcommons.Imu.edu/llr/vol30/iss2/4

Kinsella, S.N. (2003 Spring). A libertarian theory of contract: title transfer, binding promises, and inalienability Journal of Libertarian Studies, 17(2), 11-37. Retrieved from http://www.mises.org/journals/jls/17_2/17_2_2.pdf

Kinsella, S.N. (2006 Sep 07). How we come to own ourselves. Retrieved from http://www.mises.org/story/2291

Kinsella, S.N. (2009A Aug 21). What Libertarianism Is. Retrieved from https://mises.org/library/whatlibertarianism

Kinsella, S.N. (2009B). What Libertarianism Is. in Hülsmann, J.G. \& Kinsella, S. eds., Property, Freedom, and Society: Essays in Honor of Hans-Hermann Hoppe. Auburn AL: Mises Institute

Kinsella, S.N. (2009C May 22). Homesteading, Abandonment, and Unowned Land in the Civil Law. Retrieved from http://blog.mises.org/10004/homesteading-abandonment-and-unowned-landin-the-civil-law/

Lipson, M., \& Vallentyne, P. (1991 Oct). Libertarianism, Autonomy, and Children. Public Affairs Quarterly, 5(4), 333-352.

Lyons, D. (1970 Feb). The Correlativity of Rights and Duties. Noûs, 4(1), 45-55.

Locke, J. (1948). An Essay Concerning the True Origin, Extent, and End of Civil Government, in E. Barker, ed., Social Contract. New York: Oxford University Press, pp. 17-19.

Long, R.T. (2010 Winter). Abortion, Abandonment and Positive Rights: The Limits of Compulsory Altruism. Social Philosophy and Policy, 10(1), 166-191.

Paul, E.F. (1987). Property Rights and Eminent Domain. Livingston, New Jersey: Transaction Publishers

Pufendorf, S. (1673). Natural law and the law of nations (De officio hominis et civis prout ipsi praescribuntur lege naturali). The Translation. New York: Oxford University Press (1927).

Ross, D. (2007, [1930]). The Right and the Good. Oxford: Oxford University Press.

Rothbard, M.N. (1969 June 15). Confiscation and the Homestead Principle. The Libertarian Forum, 1(6). Retrieved from https://www.panarchy.org/rothbard/confiscation.html

Rothbard, M.N. (2006 [1973]). For a New Liberty. Auburn, Alabama: Ludwig von Mises Institute.

Rothbard, M.N. (1998 [1982]). The Ethics of Liberty. New York: New York University Press.

Rozeff, M.S. (2005 Sep 01). Original Appropriation and Its Critics. Retrieved from http://www.lewrockwell.com/rozeff/rozeff18.html

Watner, C. (1982). The Proprietary Theory of Justice in the Libertarian Tradition. Journal of Libertarian Studies, 6(3-4), 289-316. https://mises.org/library/proprietary-theory-justice-libertarian-tradition

Wenar, L. (2005 July). The Nature of Rights. Philosophy \& Public Affairs, 33(3), 223-252.

Whitehead, R., \& Block, W.E. (2003). Taking the assets of the criminal to compensate victims of violence: a legal and philosophical approach. Wayne State University Law School Journal of Law in Society, 5(1), 229-254.

Wikipedia. (2018, May 23). Emancipation of minors. Retrieved from Wikipedia: https://en.wikipedia.org/wiki/Emancipation_of_minors

Received for publication: $\quad 26.04 .2018$

Revision received: $\quad 30.05 .2018$

Accepted for publication: $\quad$ 07.06.2018 


\section{How to cite this article?}

Style - APA Sixth Edition:

Varricchio, M., \& Block, W. E. (2018, July 15). Runaway Children and Starvation. (Z. Cekerevac, Ed.) MEST Journal, 6(2), 150-157. doi:10.12709/mest.06.06.02.18

Style - Chicago Sixteenth Edition:

Varricchio, Marino, and Walter E. Block. 2018. "Runaway Children and Starvation." Edited by Zoran Cekerevac. MEST Journal (MESTE) 6 (2): 150-157. doi:10.12709/mest.06.06.02.18.

Style - GOST Name Sort:

Varricchio Marino and Block Walter E. Runaway Children and Starvation [Journal] // MEST Journal / ed. Cekerevac Zoran. - Toronto : MESTE, July 15, 2018. - 2 : Vol. 6. - pp. 150-157.

Style - Harvard Anglia:

Varricchio, M. \& Block, W. E., 2018. Runaway Children and Starvation. MEST Journal, 15 July, 6(2), pp. 150-157.

Style - ISO 690 Numerical Reference:

Runaway Children and Starvation. Varricchio, Marino and Block, Walter E. [ed.] Zoran Cekerevac. 2, Toronto : MESTE, July 15, 2018, MEST Journal, Vol. 6, pp. 150-157. 